\title{
Status of Botulism in the United States
}

\author{
B. J. OSHeroff, B.S., G.G. SLOCUM, Ph.D., and W. M. DECKER, D.V.M.
}

$\mathrm{I}^{\mathrm{N}}$ NCREASED incidence of botulism in the United States in 1963, the year of the Michigan outbreak from canned tuna fish, heightened the keen and continuing interest of the Public Health Service, the Food and Drug Administration, other Federal agencies, and industry in control and suppression of this disease.

\section{Epidemiology}

Meyer, in his classic review on food poisoning, says of botulism (1) : "This is a specific intoxication with toxins of Clostridium botulinum or parabotulinum. The five serotypes, $\mathbf{A}$, $\mathrm{B}, \mathrm{C}, \mathrm{D}$, and $\mathrm{E}$, exist in nature as sporulating saprophytes and grow freely in a great variety of inadequately preserved animal or plant foods. During resultant spoilage a powerful toxin is formed and, on ingestion, is absorbed, ultimately inducing some changes in the motornerve terminals at the neuromuscular junction; acetylcholine output is diminished, with effects resembling denervation. The name botulism (from botulus, sausage) has, at least in the United States, lost its significance, since animal products play a subordinate role here. Most outbreaks are caused by inadequately preserved, understerilized plant products. . . .

"Up to 1925 , commercially canned foods manufactured in the United States were at fault in

Mr. Osheroff is program analysis officer, Division of Public Health Methods, Public Health Service; Dr. G. G. Slocum is chief, Division of Microbiology, Food and Drug Administration; and Dr. Decker is chief, Special Projects Section, Milk and Food Branch, Division of Environmental Engineering and Food Protection, Public Health Service.
32 cases, but intensive research, supported by the protective measures originally devised by the State of California, led to the adoption of scientific procedures by the canning industry."

In another paper, Meyer and Eddie present a collection of tabular data on botulism in the United States and Canada for the period 18991949 (2). Much of their information on outbreaks of botulism relates to a wide variety of home-processed foods. Unfortunately since the paper was published, additional information of this kind has not been available in so complete a form.

The Public Health Service has records, however, on reported cases of botulism for the years 1950-63 (State reports received by the National Office of Vital Statistics and the Communicable Disease Center). A recent Public Health Service Morbidity and Mortality Report presents an overview and analysis of the known epidemiology to January 1964 (3).

From 1899 through 1963, 1,561 cases of botulism were reported in the United States (table 1). The greatest number was in the decade 1930-39; the second greatest, 1920-29; the third greatest, 1940-49. Home-processed foods have been the most commonly implicated sources of infection in the past three or four decades. $C$. botulinum types $\mathbf{A}$ and $\mathrm{B}$ were most often responsible for outbreaks arising from the noncommercially processed foods.

Records relating to botulism in the United States caused by consumption of commercially prepared foods (records more accurate than those relating to noncommercially prepared foodstuffs) are summarized in table 2 . In the period 1906-63, 51 outbreaks involving commercially prepared foods were reported, with 109 
deaths in a total of 219 cases. To the best of our knowledge the implicated foods had been processed by canning, pickling, smoking, and vacuum packaging. Little information is available on the relationship of the specific temperature and time of food processing to the reported outbreaks.

A review of the commercially prepared foods

Table 1. Botulism cases in the United States, 1899-1963, by decade

\begin{tabular}{|c|c|c|c|c|c|c|c|c|}
\hline States & 1899-1909 & 1910-19 & $1920-29$ & $1930-39$ & $1940-49$ & $1950-59$ & $1960-63$ & Total \\
\hline $\begin{array}{l}\text { California } \\
\text { Washington } \\
\text { Colorado } \\
\text { New Mexico } \\
\text { New York } \\
\text { Michigan } \\
\text { Oregon } \\
\text { Tennessee } \\
\text { Kentucky } \\
\text { Montana }\end{array}$ & $\begin{array}{r}11 \\
0 \\
0 \\
0 \\
0 \\
0 \\
0 \\
0 \\
0 \\
0\end{array}$ & $\begin{array}{r}104 \\
23 \\
17 \\
0 \\
18 \\
15 \\
3 \\
0 \\
0 \\
7\end{array}$ & $\begin{array}{r}87 \\
43 \\
27 \\
0 \\
21 \\
34 \\
18 \\
7 \\
0 \\
5\end{array}$ & $\begin{array}{r}105 \\
46 \\
31 \\
37 \\
19 \\
0 \\
20 \\
15 \\
11 \\
17\end{array}$ & $\begin{array}{r}109 \\
30 \\
23 \\
33 \\
12 \\
2 \\
12 \\
6 \\
11 \\
3\end{array}$ & $\begin{array}{r}50 \\
15 \\
25 \\
7 \\
0 \\
0 \\
3 \\
5 \\
11 \\
2\end{array}$ & $\begin{array}{r}12 \\
8 \\
2 \\
3 \\
2 \\
9 \\
0 \\
15 \\
10 \\
0\end{array}$ & $\begin{array}{r}478 \\
165 \\
125 \\
80 \\
72 \\
60 \\
56 \\
48 \\
43 \\
34\end{array}$ \\
\hline $\begin{array}{l}\text { North Dakota. } \\
\text { Ohio } \\
\text { Wyoming } \\
\text { Nebraska } \\
\text { New Jersey } \\
\text { Idaho } \\
\text { Mississippi } \\
\text { Indiana } \\
\begin{array}{l}\text { Pennsylvania. } \\
\text { Illinois. }\end{array}\end{array}$ & $\begin{array}{l}0 \\
0 \\
0 \\
0 \\
0 \\
0 \\
0 \\
0 \\
0 \\
0\end{array}$ & $\begin{array}{r}0 \\
14 \\
0 \\
2 \\
3 \\
4 \\
0 \\
7 \\
0 \\
4\end{array}$ & $\begin{array}{r}0 \\
12 \\
21 \\
3 \\
2 \\
2 \\
0 \\
11 \\
9 \\
4\end{array}$ & $\begin{array}{r}21 \\
3 \\
8 \\
12 \\
5 \\
8 \\
0 \\
0 \\
1 \\
0\end{array}$ & $\begin{array}{r}9 \\
0 \\
0 \\
10 \\
4 \\
0 \\
4 \\
0 \\
3 \\
2\end{array}$ & $\begin{array}{r}0 \\
1 \\
0 \\
0 \\
13 \\
6 \\
17 \\
2 \\
2 \\
6\end{array}$ & $\begin{array}{l}0 \\
0 \\
0 \\
0 \\
0 \\
3 \\
0 \\
0 \\
3 \\
0\end{array}$ & $\begin{array}{l}30 \\
30 \\
29 \\
27 \\
27 \\
23 \\
21 \\
20 \\
18 \\
16\end{array}$ \\
\hline 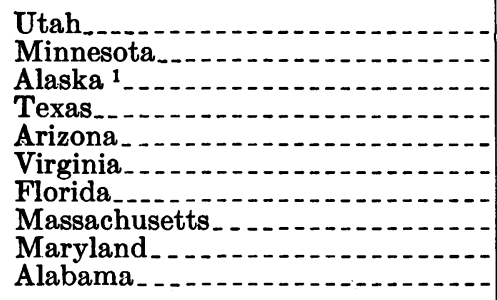 & $\begin{array}{l}0 \\
0 \\
0 \\
0 \\
0 \\
0 \\
0 \\
0 \\
0 \\
0\end{array}$ & $\begin{array}{l}1 \\
0 \\
0 \\
0 \\
0 \\
0 \\
7 \\
6 \\
0 \\
0 \\
0\end{array}$ & $\begin{array}{l}0 \\
0 \\
0 \\
6 \\
5 \\
0 \\
0 \\
0 \\
0 \\
3\end{array}$ & $\begin{array}{l}1 \\
5 \\
0 \\
4 \\
0 \\
2 \\
0 \\
2 \\
0 \\
0\end{array}$ & $\begin{array}{r}12 \\
0 \\
0 \\
0 \\
4 \\
5 \\
0 \\
0 \\
4 \\
1\end{array}$ & $\begin{array}{r}0 \\
3 \\
10 \\
1 \\
2 \\
2 \\
0 \\
0 \\
3 \\
0\end{array}$ & $\begin{array}{l}0 \\
5 \\
3 \\
0 \\
0 \\
0 \\
0 \\
1 \\
0 \\
0 \\
3\end{array}$ & $\begin{array}{r}14 \\
13 \\
13 \\
11 \\
11 \\
9 \\
8 \\
8 \\
7 \\
7\end{array}$ \\
\hline $\begin{array}{l}\text { South Dakota } \\
\text { Nevada } \\
\text { Wisconsin } \\
\text { Oklahoma } \\
\text { Connecticut, } \\
\text { Iowa } \\
\text { Maine } \\
\text { West Virginia } \\
\text { Louisiana } \\
\text { Washington, D.C. }\end{array}$ & $\begin{array}{l}0 \\
0 \\
0 \\
0 \\
0 \\
0 \\
0 \\
0 \\
0 \\
0\end{array}$ & $\begin{array}{l}0 \\
0 \\
3 \\
0 \\
0 \\
5 \\
0 \\
0 \\
0 \\
0\end{array}$ & $\begin{array}{l}0 \\
0 \\
2 \\
0 \\
0 \\
0 \\
4 \\
0 \\
0 \\
0\end{array}$ & $\begin{array}{l}5 \\
0 \\
1 \\
2 \\
1 \\
0 \\
0 \\
0 \\
0 \\
0\end{array}$ & $\begin{array}{l}2 \\
3 \\
0 \\
1 \\
4 \\
0 \\
0 \\
3 \\
0 \\
3\end{array}$ & $\begin{array}{l}0 \\
3 \\
0 \\
3 \\
0 \\
0 \\
0 \\
0 \\
3 \\
0\end{array}$ & $\begin{array}{l}0 \\
0 \\
0 \\
0 \\
0 \\
0 \\
0 \\
0 \\
1 \\
1 \\
0\end{array}$ & $\begin{array}{l}7 \\
6 \\
6 \\
6 \\
5 \\
5 \\
4 \\
4 \\
4 \\
3\end{array}$ \\
\hline $\begin{array}{l}\text { Arkansas } \\
\text { Missouri- } \\
\text { North Carolina } \\
\text { Georgia } \\
\text { Hawaii } 1 . \\
\text { New Hampshire Hon } \\
\text { Vermont } \\
\text { Rhode Island } \\
\text { Kansas } \\
\text { Delaware } \\
\text { South Carolina. }\end{array}$ & $\begin{array}{l}0 \\
0 \\
0 \\
0 \\
0 \\
0 \\
0 \\
0 \\
0 \\
0 \\
0\end{array}$ & $\begin{array}{l}0 \\
0 \\
0 \\
0 \\
0 \\
0 \\
0 \\
0 \\
0 \\
0 \\
0\end{array}$ & $\begin{array}{l}0 \\
2 \\
0 \\
0 \\
0 \\
0 \\
0 \\
0 \\
0 \\
0 \\
0\end{array}$ & $\begin{array}{l}2 \\
0 \\
0 \\
0 \\
0 \\
0 \\
0 \\
0 \\
0 \\
0 \\
0\end{array}$ & $\begin{array}{l}0 \\
0 \\
0 \\
1 \\
0 \\
0 \\
0 \\
0 \\
0 \\
0 \\
0\end{array}$ & $\begin{array}{l}0 \\
0 \\
2 \\
0 \\
0 \\
0 \\
0 \\
0 \\
0 \\
0 \\
0\end{array}$ & $\begin{array}{l}1 \\
0 \\
0 \\
0 \\
0 \\
0 \\
0 \\
0 \\
0 \\
0 \\
0\end{array}$ & $\begin{array}{l}3 \\
2 \\
2 \\
1 \\
0 \\
0 \\
0 \\
0 \\
0 \\
0 \\
0\end{array}$ \\
\hline Total & 11 & 243 & 328 & 384 & 316 & 197 & 82 & 1,561 \\
\hline
\end{tabular}

1 Since 1950 only.

SourCE: 1899-1949 based on data collected by K. F. Meyer and B. Eddie (2); 1950-63 data from State reports to National Office of Vital Statistics and the Communicable Disease Center. 
implicated in outbreaks in the period 1950-63 indicates that only 5 cases of a total of 44 were attributable to canned food products. The remaining 39 cases were associated with the consumption of products receiving no heat treatment, such as cheese or smoked fish not processed at temperatures capable of destroying $C$. botulinum. Table 2 shows $C$. botulinum type $\mathrm{E}$ has been the major cause of cases of botulism from commercially prepared foods in the United States in the past two decades. A review of the known outbreaks of type $\mathrm{E}$ botulism in the pe- riod 1932-63 (table 3) shows that the foods most often implicated were unprocessed, processed at relatively low temperatures, or simply air dried.

In 1963, 46 cases of botulism were reported in the United States (table 4). These cases, which included 14 deaths and occurred in 12 outbreaks, represent the highest total for any one year since 1939 and the eighth highest since 1899. Commercially canned food products accounted for 5 cases with 2 deaths; commercially smoked products, for 19 cases with 7 deaths; home-processed foods for 22 cases with

Table 2. Botulism outbreaks in the United States associated with commercial foods

\begin{tabular}{|c|c|c|c|c|c|}
\hline Year & Food & Outbreaks & Cases & Deaths & Type \\
\hline $\begin{array}{l}1921 \ldots \ldots \\
1922 \ldots \ldots \\
1924 \ldots \\
1925 \ldots \ldots \\
1929 \ldots \ldots \\
1931 \ldots \\
1934 \ldots \\
1936 \ldots \ldots \\
1938 \ldots \\
1941 \\
1951 \\
1960 \ldots \ldots\end{array}$ & 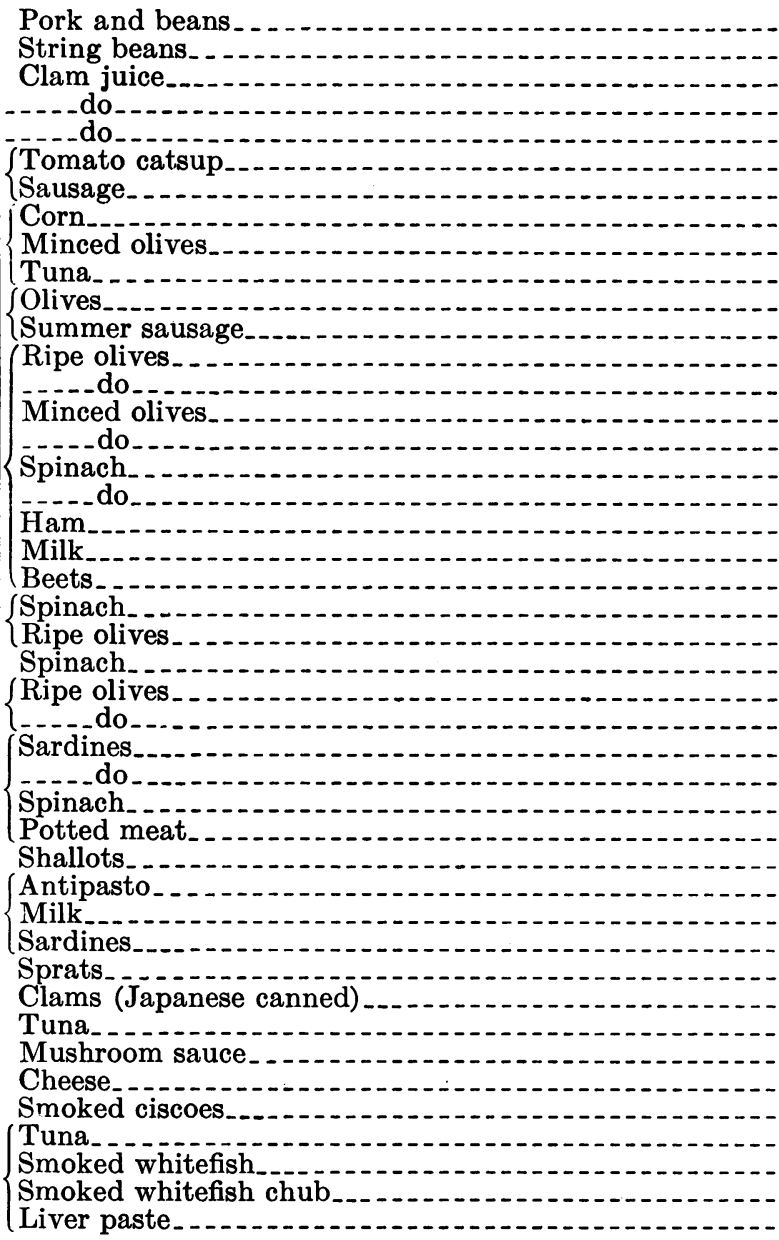 & $\begin{array}{l}1 \\
1 \\
1 \\
1 \\
1 \\
1 \\
1 \\
1 \\
1 \\
1 \\
3 \\
1 \\
1 \\
2 \\
1 \\
1 \\
1 \\
1 \\
1 \\
1 \\
1 \\
3 \\
1 \\
2 \\
2 \\
1 \\
1 \\
1 \\
1 \\
1 \\
1 \\
1 \\
1 \\
1 \\
1 \\
1 \\
1 \\
1 \\
1 \\
1 \\
1 \\
1 \\
1 \\
1\end{array}$ & $\begin{array}{r}3 \\
4 \\
2 \\
3 \\
2 \\
2 \\
2 \\
1 \\
2 \\
1 \\
28 \\
3 \\
7 \\
2 \\
5 \\
1 \\
6 \\
2 \\
4 \\
4 \\
5 \\
32 \\
5 \\
11 \\
13 \\
9 \\
2 \\
2 \\
5 \\
4 \\
2 \\
3 \\
1 \\
2 \\
3 \\
4 \\
2 \\
3 \\
1 \\
2 \\
3 \\
2 \\
17 \\
2\end{array}$ & $\begin{array}{r}3 \\
4 \\
1 \\
2 \\
2 \\
0 \\
2 \\
0 \\
2 \\
1 \\
17 \\
0 \\
7 \\
0 \\
1 \\
1 \\
3 \\
2 \\
4 \\
0 \\
5 \\
4 \\
3 \\
6 \\
6 \\
2 \\
2 \\
2 \\
1 \\
4 \\
1 \\
1 \\
0 \\
1 \\
1 \\
4 \\
2 \\
1 \\
1 \\
2 \\
2 \\
2 \\
5 \\
0\end{array}$ & 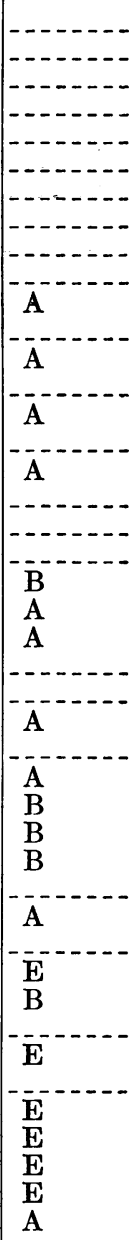 \\
\hline & Total & 51 & 219 & 109 & \\
\hline
\end{tabular}

Source: 1899-1949 based on data collected by K. F. Meyer and B. Eddie (2); 1950-63 data from State reports to National Office of Vital Statistics and the Communicable Disease Center. 
5 deaths. $C$. botulinum type B toxin was identified as the etiological agent in 4 of the 12 outbreaks (11 cases), type $\mathrm{E}$ toxin in 3 outbreaks (22 cases), and type A in 2 outbreaks (4 cases). In the remaining three outbreaks (nine cases), the type was unknown (table 5).

\section{Regulations and Recommendations}

Application of the Food, Drug, and Cosmetic Act by the Food and Drug Administration helps protect the consuming public against the hazards of botulism from foods in interstate com- merce. Also in press releases on outbreaks, such as those in 1963 caused by canned tuna and smoked fish, the agency warns of the particular hazard and describes emergency actions taken to protect the public health.

Commercially canned foods. Measures for prevention of the development of botulism toxin in canned foods depend on application of heat processes adequate to destroy the spores of $C$. botulinum in foods in hermetically sealed containers. The research laboratories of the canning and can-manufacturing industries have defined these requirements (4), and commercial

Table 3. Known outbreaks of type $E$ botulism in the United States

\begin{tabular}{|c|c|c|c|c|}
\hline Year & State & Food & Cases & Deaths \\
\hline 1932 & New York & Smoked salmon (Canadian origin) & 3 & 1 \\
\hline 1934 & New York & Sprats (German origin) & 3 & 1 \\
\hline 1941 & California_ & Mushroom sauce (mushrooms Yugoslav origin) & 3 & $\mathbf{1}$ \\
\hline 1950 & Alaska (Point Hope) & Muktuk (dried beluga flipper) & 5 & 0 \\
\hline 1952 & Alaska (Selawik) _... & - & 1 & 1 \\
\hline 1956 & Alaska (Kotzebue) & {$[-\ldots$ do } & 3 & 2 \\
\hline 1956 & Alaska (Anchorage) - - & 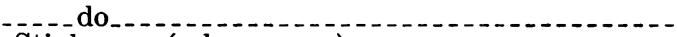 & 2 & 1 \\
\hline 1959 & Alaska (Hydaburg) $\ldots . .$. & Stink eggs (salmon eggs) _. . & 1 & 1 \\
\hline $1959 \ldots$ & Alaska (Scammon Bay) _. & Seal or whale flipper & 7 & 1 \\
\hline $1960 \ldots$ & Alaska (Ketchikan) ..... & Stink eggs (fermented Ketdukon salmon eggs) - - & 2 & \\
\hline $1960 \ldots$ & Minnesota $\ldots \ldots \ldots$ & $\begin{array}{l}\text { Ciscoes (vacuum-packed smoked, caught in Lake } \\
\text { Superior). }\end{array}$ & 2 & 2 \\
\hline 1961 . & Washington & Uncooked salmon eggs & 4 & 1 \\
\hline 1963 & Michigan... & Tuna (Japanese origin, California packed) & 3 & 2 \\
\hline 1963 & Michigan............. & Smoked whitefish & 2 & \\
\hline 1963 & Tennessee, Alabama & $\begin{array}{l}\text { Smoked whitefish chubs (vacuum packed in } \\
\text { Michigan). }\end{array}$ & 17 & 5 \\
\hline Total_. & & & 58 & 23 \\
\hline
\end{tabular}

SoURCE: Reference 3.

Table 4. Known autbreaks of botulism in the United States, 1963

\begin{tabular}{|c|c|c|c|c|c|}
\hline Location & Food & Processor & $\begin{array}{l}\text { Type of } \\
\text { botulism }\end{array}$ & Cases & Deaths \\
\hline California_........ & Chili peppers $\ldots$ & Noncommercial . . . & & 2 & 0 \\
\hline New York City & Liver paste $\ldots . . . . . . . . .$. & Commercial & A. & 2 & 0 \\
\hline West Virginia & Green beans & Noncommercial _. & B. & 1 & 1 \\
\hline Kentucky & Corn & - do & B & 5 & 1 \\
\hline Colorado_... & Green beans & $\ldots$ do $\ldots \ldots$. & B & 2 & 1 \\
\hline Pennsylvania & $\ldots$. & $\ldots$ do $\ldots . . . .$. & B. & 3 & $\mathbf{0}$ \\
\hline Michigan & Tuna fish $\ldots . . . .$. & Commercial & E. & 3 & 2 \\
\hline Michigan & Smoked whitefish & $\ldots$. & E. & 2 & 2 \\
\hline Tennessee, Alabama, and & Smoked whitefish chub_.- & $\ldots$ do $\ldots$ do......... & $\mathbf{E}_{-\ldots}$ & 17 & $\mathbf{5}$ \\
\hline California_._. & Mushrooms & Noncommercial_. _ & Unknown $\ldots . .$. & 6 & 1 \\
\hline Minnesota _. & Smoked whitefish & $\ldots$ - do & $\ldots$ _. do $_{\ldots} \ldots \ldots$ & 1 & 0 \\
\hline California & Figs _ . . . . . . . & - do do & . $\ldots$ do $\mathrm{d}_{\ldots} \ldots \ldots$ & 2 & 1 \\
\hline Total & & & & 46 & 14 \\
\hline
\end{tabular}

Source: State reports to the Communicable Disease Center, Public Health Service, Atlanta, Ga. 


\section{Antitoxin Treatment}

Administration of antitoxin is the only specific treatment against botulism. A limited supply of type $E$ antitoxin is available on a 24-hour service from the Communicable Disease Center, Public Health Service, Atlanta, Ga. It is otherwise commercially unavailable in the United States.

canners have applied them so generally that their products have virtually been eliminated as sources of botulism. An item in a 1964 issue of the National Canners Association's Information Letter is of interest in this connection (5).

Control of commercially canned foods is based upon the requirements of the Food, Drug, and Cosmetic Act, section 402(a). The act defines a food as adulterated "if it bears or contains any poisonous or deleterious substances which may render it injurious to health; ... or if it consists in whole or in part of any filthy, putrid, or discomposed substance, or if it is otherwise unfit for food; or if it has been prepared, packed, or held under insanitary conditions whereby it may have become contaminated with filth, or whereby it may have been rendered injurious to health; ..."

Under provisions of the act, canneries are inspected at intervals to determine, among other things, whether the heat processes recommended by the National Canners Association are applied and the adequacy of the controls exercised by the canning firms. It has been the experience of the Food and Drug Administration that the use of adequate heat processes and of effective can closures is a commercial necessity if canners are to avoid severe economic loss from spoilage.

In its investigation of the 1963 canned tuna outbreak, the Food and Drug Administration showed that the tuna had received adequate heat processes at the California canning plant but was contaminated after processing through defective closures in some cans. Nearly 3,300 ( 0.5 percent) of the 650,000 cans of tuna from the plant examined by FDA inspectors were classed as abnormal; in a large proportion of the 3,300 cans, abnormalities were caused by defective closure of the lids at the cannery. Twenty-two cans were found to contain $C$. botulinum; many others were contaminated with nontoxic micro-organisms. $C$. botulinum type E was isolated from four locations on the equipment which handled the cans after heat processing. By contrast, abnormal cans were extremely rare in the shipments of other tuna packers, and no evidence of significant contamination was found.

The Food and Drug Administration warned consumers, through press releases and other publicity, to discard without eating or testing any food which appeared or smelled abnormal and to avoid use of foods in bulging or leaking cans.

The Food and Drug Administration is taking steps to prevent a recurrence of the 1963 tuna episode. It is continuing efforts to determine the basic reason for the defective can closures in the California plant. Whether this resulted from malfunction of the can-closing machines, faults in can structures, or other causes is still not clear. Bacteriological studies in other tuna canneries have been conducted to detect possible sources of contamination with $C$. botulinum; findings have been negative. Since the safety of canned goods depends upon the exercise, on a continuing basis, of strict control of can-sealing and processing operations, the agency is undertaking increased inspections to check on the adequacy of controls exercised by canneries.

Minimum processes for canned foods are not prescribed in the Food, Drug, and Cosmetic Act or in the regulations promulgated thereunder. To our knowledge, only the State of California prescribes such minimum processes in the United States. The Food and Drug Ad-

\section{Table 5. 1963 botulism in the United States, by specific type}

\begin{tabular}{r|r|r|r}
\hline Type & Outbreaks & Cases & Deaths \\
\hline A & 2 & 4 & 0 \\
\hline Total & 4 & 11 & 3 \\
& 3 & 22 & 9 \\
\hline
\end{tabular}

Source: State reports to the Communicable Disease Center. 
ministration is considering the desirability and feasibility of promulgating such regulations under the act.

The agency is also examining problems which may arise in connection with new can-making techniques and materials, as well as with highspeed can-handling equipment, including problems of sanitation resulting from improper equipment design.

Home-canned foods. Most outbreaks of botulism in the United States during the past 30 or 40 years have been traced to home canning, as already noted; usually improperly or inadequately processed nonacid foods were implicated. The outbreaks generally result from failure to apply safe and effective processes for home canning. Such processes have been described and given wide distribution in numerous publications $(6,7)$, announcements, demonstrations, and courses of the Department of Agriculture and its State Extension Service. Prevention and control of botulism outbreaks from home canning obviously depend on continued efforts to teach the homemaker proper food-processing methods, including the safeguards necessary to insure a wholesome product.

Smoked fish and other fish products. After the 1963 outbreaks of botulism in the United States from consumption of fish products, an Advisory Committee on Botulism Hazard (8) was appointed to advise the Food and Drug Administration on emergency measures to prevent botulism from the consumption of smoked fish. Recommended and adopted by the Food and Drug Administration and the smoked fish industry, these measures will remain in effect with respect to interstate commerce in smoked fish products processed in establishments in the Great Lakes area or from Great Lakes fish smoked in establishments in other parts of the country. In our opinion the measures should not be modified until the total research efforts of government and industry provide other or better means to insure the marketing of smoked fish products free from the botulism hazard. $C$. botulinum type $\mathrm{E}$ does not produce obvious spoilage in fishery products to warn of its presence. Therefore, measures to eliminate traffic in contaminated fish products are essential to consumer protection.

\section{Research}

The increased incidence of botulism during 1963 stimulated a renewed interest in reasearch. At least six agencies of the Federal Government currently support studies related to botulism :

Agency

Public Health Service...--- -

Food and Drug Administration........................

Atomic Energy Commission.

Department of Defense, Army Quartermaster

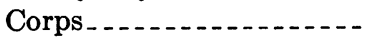

National Science Foundation

Department of Interior, Fish and Wildlife Service.

Total

1 Not identifiable.

Both the Food and Drug Administration and the Public Health Service maintain liaison with the other governmental programs through a flow of information and cooperative projects.

Public Health Service. The Public Health Service, through its research grant program, supports the following botulism studies (funds given in total amounts, not annual) :

Effect of irradiation of clostridial antigens (EF00017), Dr. Nancy W. Walls, Georgia Institute of Technology, September 1, 1961, $\$ 65,494$.

Conditions for growth of Clostridium botulinum in tomatoes (EF-00130), Dr. Charles T. Townsend, National Canners Association, Berkeley, Calif., April 1, $1960, \$ 65,549$.

Associative growth of Clostridium botulium in milk (EF-00161), Dr. O. W. Kaufmann, Michigan State University, May 1, 1959, $\$ 22,121$.

Toxin formation by Clostridium botulinum type $\mathbf{E}$ (EF-00361), Dr. Ganji Sakaguchi, National Institute of Health, Tokyo, December $1,1962, \$ 11,739$.

Mechanism of resistance of Clostridium botulinum spores (EF-00517), Dr. Nicholas Greca, Illinois Institute of Technology, September 1, 1963, $\$ 125,032$.

Thermal destruction of type E Clostridium botulinum spores (EF-00517), Dr. Nicholas Greca, Illinois Institute of Technology, September 1, 1963, $\$ 125,032$.

Thermal destruction of type $\mathbf{E}$ Clostridium botulinum (EF-00632), Dr. C. Wallace Bohrer, Nationa] Canners Association, Washington, D.C., action pending, $\$ 39,000$ (not included in $\$ 391,135$ total).

Chemistry and biological activity of botulinum toxin (A1-04180), Dr. Daniel A. Boroff, Albert Einstein Medical Center, Philadelphia, $\$ 109,500$. 
Micro-electrode studies of human skeletal muscle (NB-03080), Dr. T. R. Johns, University of Virginia, $\$ 73,500$.

Food and Drug Administration. The Food and Drug Administration is conducting market studies to determine the incidence, if any, of C. botulinum type $\mathrm{E}$ in smoked fish. It is also conducting intramural research on laboratory methods and on factors affecting the growth of the organism. To determine the foci of $C$. botulinum type $\mathrm{E}$ in fish-smoking plants, the agency has contracted for a 1-year ecological study at a cost of $\$ 12,000$ (subject to renegotiation in both time and amount). An additional contract is planned for the support of similar studies on the west coast, under Dr. K. S. Pilcher of Oregon State University, at a cost of approximately $\$ 20,000$.

Atomic Energy Commission. The Atomic Energy Commission (Biology Branch, Division of Biology and Medicine) is conducting the following work by contracts:

A study on effect of ionizing radiation on resistance, germination, and toxin synthesis of $C$. botulinum spores, types A, B, and E, University of Michigan, 3 years, $\$ 107,000$.

Evaluation of public health hazards involved in the prolongation of refrigerated storage life of foods by application of low doses of ionizing radiation, Continental Can Company, 2 years, $\$ 20,000$. (Factors which govern the hazards of $C$. botulinum type $E$ in refrigerated foods are to be established.)

Survey of sea mud, crab gut, and flotation tanks for incidence of Clostridium botulinum type $\mathrm{E}$ spores, $\mathrm{Bu}$ reau of Commercial Fisheries, Seattle, Wash., 1 year, $\$ 32,300$.

Inoculated pack study on irradiated haddock filets and soft shell clams, using $C$. botulinum type E, Massachusetts Institute of Technology, 1 year, $\$ 56,000$.

Department of Defense. Under its internal research program, the Defense Department is conducting the following studies, consisting of three major aspects :

The first, termed "process work," is seeking to determine the minimal sterilizing radiation dose for foods, using $C$. botulinum types $\mathbf{A}$ and $B$ as indicator organisms. The food is irradiated at various dose levels, and relative resistance is calculated by conventional culture methods or recovery. Also some work is being done on the effect of such processing variables, as acidity, temperature, chemicals present, and moisture content, as well as on microwave processing in conjunction with radiation.

Under the second, or "basic aspects" phase (that is, the mode of radioresistance of spores), Defense scientists are studying the sporulation, germination, and outgrowth of spores and their biophysical and chemical characteristics as affected by radiation processing.

A third aspect under study on the toxin of C. botulinum organisms includes the study of the physiology of toxic production, improved methods for quantitative assay of toxin presence, and the effects of radiation on toxin present in foods.

The second and third aspects of the Defense Department study are in preliminary stages, pending completion of adequate facilities for handling the highly toxic research material; adequately trained personnel for the program is available.

Under Defense Department contract are two rather small projects, both conducted by Swift \& Co. The first, now in its final phases, relates to a comparison of thermal processing of cured (canned) meats by radiation. The second project, just beginning, will survey raw meat, chicken, beef, ham, and the like to determine the natural incidence of spores in $C$. botulinum types A and B.

National Science Foundation. The National Science Foundation is supporting one study :

Pharmacology, chemistry, and toxicology of botulinum toxin, Dr Daniel A. Boroff, Albert Einstein Medical Center, Philadelphia, $2 \frac{1}{2}$ years, $\$ 90,000$.

Department of the Interior. The Fish and Wildlife Service of the Department of the Interior supports two studies by contract, one with the University of Wisconsin and the other with Michigan State University. Both studies are attempting to determine the distribution of C. botulinum type $\mathrm{E}$ in nature, particularly in the biological media of the Great Lakes.

In addition to basic control measures, including epidemiologic and ecological investigations and recommendations and regulations, the Public Health Service, the Food and Drug Administration, and other interested Federal Government agencies coordinate U.S. basic and applied research programs with foreign governments and industries in order to keep abreast with 
and encourage further development of the basic scientific and medical skills necessary to control and suppress botulism.

\section{REFERENCES}

(1) Meyer, K. F.: Food poisoning. New Eng J Med 249 : 765-773, Nov. 5, 1953; 804-812, Nov. 12, 1953 ; 843-852, Nov. 19, 1953.

(2) Meyer, K. F., and Eddie, B.: Fifty years of botulism in the United States and Canada. George Williams Hooper Foundation, University of California, San Francisco, July 1950.

(ङ) U.S. Public Health Service : Morbidity and mortality weekly report 12: No. 1, Jan. 10, 1964.

(4) National Canners Association Research Laboratory: Processes for low-acid canned foods in metal containers. Bulletin 26-L, 8th ed., December 1955.

(5) U.S. Food and Drug Administration: A close look at canned food containers. Reprint from National Canners Association Information Letter No. 1959, Febraury 15, 1964, containing proceedings of the 57th annual National Canners Association Convention, held February 2-5, Dallas, Tex.

(6) U.S. Department of Agriculture : Home canning of fruits and vegetables. Home and Garden Bulletin No. 8. Revised. February 1957.

(y) U.S. Department of Agriculture: Home canning of meat. Home and Garden Bulletin No. 6. Revised. September 1963.

(8) U.S. Public Health Service: Symposium on botulism; and roster, Cincinnati, January 13-15, 1964.

\section{Increase in Number of Diabetics}

Four million or more persons in the United States have diabetes according to latest estimates of known and unknown cases. As recently as 1962 the total number was estimated to be 3 million.

Data from the Sudbury Health Study, the Tecumseh Community Health Study, the Federal Employee Screening Program, and a study of 6,672 persons carried out by the National Center for Health Statistics show a higher rate of diabetes than would have been expected from past concepts or prevalence.

Dr. Glen W. McDonald, chief of the Diabetes and Arthritis Program, Division of Chronic Diseases, Public Health Service, attributed the rising rate to the increasing number of older persons and of overweight persons, broader diagnostic concepts, the possibility that more persons inherit the disease, and more sensitive screening tests.

Early identification of the diabetic who carries the strain but does not know that he has diabetes is an important health goal, Dr. McDonald said. "By prescribing medication and regulating diet and exercise, we believe that physicians will soon be able to delay the onset of the disease. When diabetes does occur, it should be less severe, bring fewer complications, and be controlled more easily."

"An annual blood test is the best protection a person can have, particularly if he is over 40 , overweight, or there is diabetes in his family," Dr. McDonald commented. 